\title{
Rat Astroglial Somatomedin/Insulin-Like Growth Factor Binding Proteins: Characterization and Evidence of Biologic Function
}

\author{
Victor K. M. Han, ${ }^{1}$ Jean M. Lauder, ${ }^{2}$ and A. Joseph D'Ercole ${ }^{1}$ \\ Departments of ${ }^{1}$ Pediatrics and ${ }^{2}$ Anatomy, School of Medicine, University of North Carolina, Chapel Hill, North Carolina \\ 27514
}

Specific binding proteins (BPs) to somatomedin/insulin-like growth factors ( $\mathrm{Sm} / \mathrm{IGFs}$ ) have been identified in conditioned media from a variety of cells in culture. By affinity crosslinking using disuccinimidyl suberate, we have covalently cross-linked radiolabeled somatomedin-C/insulin-like growth factor I (Sm-C/IGF I), insulin-like growth factor II (IGF II) and insulin to BPs in conditioned medium (CM) from cultured astroglial cells derived from cerebral cortices of neonatal rats. Two species of radiolabeled Sm/IGF BP complexes of 40,000 Da (40K) and 45K were identified. Competition with unlabeled Sm-C/IGF I and IGF II demonstrated that the BPs in each complex have similar affinities for Sm-C/IGF I and IGF II. The BP in the $45 \mathrm{~K}$ complex was about 5 -fold more sensitive to competition with unlabeled Sm/IGFs than the BP in the $40 \mathrm{~K}$ complex, suggesting that it either has a higher affinity for Sm/lGFs or is less abundant. Evidence that the BPs in each complex are distinct includes the following findings: (1) insulin competed with $\mathrm{Sm} / \mathrm{IGF}$ for binding to the 45K complex, but not the $40 \mathrm{~K}$ complex, and (2) the BP in the 40K complex, but not the $45 \mathrm{~K}$ complex, was recognized by antibodies raised against a BP purified from $\mathrm{CM}$ of buffalo rat liver (BRL) 3A cells. Growth hormone did not affect the apparent secretion of either BP. The binding activity of both BPs was retained after mild heat treatment, changes to extremes of $\mathrm{pH}(2-10)$, and prolonged storage at $-20^{\circ} \mathrm{C}$, but was destroyed after heating to higher temperatures $\left(80^{\circ} \mathrm{C}\right.$ and greater), reduction, and proteolytic treatment. Neither BP appeared to be glycosylated because treatment with endoglycosidase-F resulted in no change in the apparent sizes of the complexes or in their capacity to bind Sm/IGFs. Identification of the BPs by a modified Western blotting technique, involving transfer of electrophoretically separated BPs to nitrocellulose membrane and blnding with ${ }^{125} \mid-\mathrm{Sm} /$ IGF, revealed BPs of about $38 \mathrm{~K}$ and $33 \mathrm{~K} \mathrm{Da}$, indicating that one

\footnotetext{
Received May 15, 1987; revised Dec. 4, 1987; accepted Jan. 22, 1988

We wish to express our thanks to Christina Mottola and Michael Czech for the generous supply of the purified BRL-3A binding protein and antibodies, to Judson Van Wyk, Marjorie Svoboda, and Peter Nissley for the generous supply of pure peptides, to Ken McCarthy for his help in purification of astroglial cells, and to Debbie Bell for technical assistance. V.K.M.H. is a recipient of a Research Fellowship frum the Medical Research Council of Canada and A.J.D. is a recipient of a Research Career Development Award from the USPHS (HD 00435). This work was supported by USPHS Grants HD08299 to A.J.D. and NS15706 to J.M.L., and the March of Dimes National Birth Defect Foundation Basic Rescarch Grant $1-758$ to A.J.D.

Correspondence should be addressed to Victor K. M. Han, M.D., The Lawson Research Institute, St. Joseph's Hospital, 268 Grosvenor Street, London, Ontario, Canada N6A 4V2.

Copyright (C) 1988 Society for Neuroscience $0270-6474 / 88 / 093135-09 \$ 02.00 / 0$
}

molecule of BP bound to one molecule of Sm/IGF. Using the BP purified from BRL-3A CM as a surrogate for the $33 \mathrm{~K}$ astroglial BP, we found that it reduced Sm-C/IGF I-stimulated ${ }^{3} \mathrm{H}$-thymidine incorporation by astroglial cells in a dose-dependent manner by binding Sm-C/IGF 1 and reducing its availability to the cell surface receptors. The latter findings suggest that the 33K BP may modulate Sm/IGF l's growthstimulating actions on astroglia. Interactions among Sm/IGFs, their binding proteins, and receptors may represent a regulatory mechanism for the control of glial growth.

Somatomedins or insulin-like growth factors ( $\mathrm{Sm} / \mathrm{IGFs}$ ) circulate in blood bound to specific binding proteins (BPs) (for reviews, see Clemmons and Van Wyk, 1981; Hintz, 1984; Smith, 1984; Nissley and Rechler, 1984). In human plasma, 2 major forms of Sm/IGF-BP complexes exist: an approximately 150,000 $\mathrm{Da}(150 \mathrm{~K})$ species that is under growth hormone $(\mathrm{GH})$ control, and a smaller species that is independent of $\mathrm{GH}$ and has a molccular wcight variously cstimated to be betwecn 30 and $50 \mathrm{~K}$. In the rat, similarly sized plasma $\mathrm{Sm} / \mathrm{IGF}-\mathrm{BP}$ complexes are observed by gel chromatography (Moses et al., 1976). In both human and rat, the $\mathrm{GH}$-independent $30-50 \mathrm{~K}$ species has been shown to be proportionately higher in fetal than in adult plasma (D'Ercole et al., 1980; White et al., 1982; Drop et al., 1984b). Such Sm/IGF BPs have been demonstrated in human amniotic fluid (Chochinov et al., 1977; Bala el al., 1978; Drop et al., 1979, 1984a; Grizzard et al., 1984), in conditioned media (CM) from human fibroblasts (Atkison et al., 1980; Clemmons et al., 1981, 1986), liver explants (Rechler et al., 1979; Binoux et al., 1980), cloned buffalo rat liver (BRL-3A) cells (Moses et al., 1979; Knauer et al., 1981; Romanus et al., 1986; Mottola et al., 1986), human hepatoma cells (Moses et al., 1983), fetal mouse limb bud explant cultures (D'Ercole et al., 1980), pancreatic beta cells (Romanus et al., 1986), and pituitary and brain explant cultures (Binoux et al., 1981). These findings suggest that Sm/ IGF BPs are produced by a variety of tissues in vitro and probably in vivo.

The physiological functions of Sm/IGF BPs are unclear. It has been suggested that BPs, by virtue of their capacity for binding $\mathrm{Sm} / \mathrm{IGFs}$, may regulate the release of these peptides at their sites of action, and thereby control the biologic function of Sm/IGFs (Nissley et al., 1977; Drop et al., 1979; Knauer and Smith, 1980; Hintz, 1984). While studying the effects of Sm/ IGFs on purified polygonal astroglial cells from neonatal rat cerebral cortices, we have identified and characterized 2 distinct species of $\mathrm{Sm} / \mathrm{IGF}$ BP secreted into culture medium by these cells. Using a BP purified from CM of BRL-3A cells, which is immunologically similar to one of the astroglial BPs character- 
ized in this study, we have shown that the BP inhibits the mitogenic action of $\mathrm{Sm} / \mathrm{IGFs}$ on astroglial cells by competing with the $\mathrm{Sm} / \mathrm{IGF}$ receptors for $\mathrm{Sm} / \mathrm{IGF}$ binding.

\section{Materials and Methods}

Materials. Sm-C/IGF I and IGF II were purified from Cohn fraction IV of human plasma, as previously described (Svoboda et al., 1980; Svoboda and Van Wyk, 1985). Multiplication-stimulating activity (MSA) III-2 was a kind gift of Dr. S. Peter Nissley, NCI, and insulin was a gift of Dr. M. Root, from E. Lilly. The peptides were iodinated with $\mathrm{Na}^{125} \mathrm{I}$ (New England Nuclear, Boston, MA) according to a modification of the chloramine-T method (Furlanetto et al., 1977) to specific activities ranging from 200 to $250 \mu \mathrm{Ci} / \mu \mathrm{g}$. The iodinated $\mathrm{Sm}-\mathrm{C} / \mathrm{IGF}$ I was further purified by immunoaffinity chromatography and the other iodinated peptides by gel filtration on a Sephadex G-50 column in $1 \mathrm{M}$ acetic acid, as previously described (Van Wyk et al., 1980). The iodinated peptides were stored in $1 \mathrm{M}$ acetic acid at $-70^{\circ} \mathrm{C}$ and used for the studies within 2 weeks of iodination. Just prior to use, the iodinated peptides were neutralized with $1 \mathrm{~m}$ sodium hydroxide to $\mathrm{pH}$ 7.0. Human growth hormone (hGH) was a gift from Kabi Vitrum (Stockholm, Sweden). The Sm/IGF BP was purified from CM of BRL-3A cells, and antibodies were raised against it, as previously described (Mottola et al., 1986). Both were the generous gift of Dr. Christina Mottola and Michael Czech (The University of Massachusetts Medical Center, Worcester, MA).

Astroglial cultures and collection of conditioned media. Relatively pure cultures of polygonal astroglial cells were prepared from cerebral cortices of 1-d-old Sprague-Dawley rats (Charles River Breeding Laboratories, Wilmington, MA), as previously described (McCarthy and de Vellis, 1980; Han et al., 1987). Briefly, 1-d-old rats were decapitated and the brains removed aseptically. The cerebral cortices were dissected and the meningeal coverings carefully peeled off. The cortical tissue was cut into small pieces and incubated in $0.1 \%$ trypsin and $0.02 \%$ EDTA solution (Gibco Laboratories, Grand Island, NY) at room temperature for 30 min with constant shaking. Trypsin activity was inhibited by the addition of twice the volume of basal medium Eagle (BME; Gibco) containing $10 \%$ fetal calf serum (FCS; Hyclone Sterile Systems, Logan, UT). The cell suspension was removed and filtered through a $130 \mu \mathrm{m}$ Nitex monofilament screen (Tetko, Elmsford, NY). The remaining tissues were triturated mechanically and filtered; the filtrate was combined with the initial cell suspension and centrifuged at $2000 \times g$. The cell pellet was gently vortexed and resuspended in complete medium (BME with $10 \% \mathrm{FCS}, 5 \mathrm{U} / \mathrm{ml}$ penicillin, and $5 \mu \mathrm{g} / \mathrm{ml}$ streptomycin). The number of viable cells was determined by the trypan blue-exclusion method in a hemacytometer ( $>90 \%$ viable). A cell suspension of $2.5-3 \times 10^{6}$ live cells $/ \mathrm{ml}$ was prepared and plated in $200 \mathrm{ml}$ tissue culture flasks $\left(75 \mathrm{~cm}^{2}\right.$ growth area). The cells were cultured at $37^{\circ} \mathrm{C}$ in $5 \% \mathrm{CO}_{2}$ and $95 \%$ air with $100 \%$ humidity for $12-14 \mathrm{~d}$, until confluence. The cells were then shaken at $270 \mathrm{rpm}$ for $18 \mathrm{hr}$ at $37^{\circ} \mathrm{C}$, and the medium containing suspended cells was removed, discarded, and replaced with new complete medium. The resulting culture consisted of more than $95 \%$ flat polygonal astroglial cells, as confirmed by phase-contrast microscopy and positive immunostaining with the antibody against glial fibrillary acid protein (GFAP; McCarthy and de Vellis, 1980). The remaining $<5 \%$ of cells consisted of process-bearing cells (about half of which were astrocytes and half oligodendrocytes), ependymal cells, and fibroblasts. Therefore, even though we cannot exclude some contribution towards the total BP content of the $\mathrm{CM}$ by the nonastrocytic cells, we believe that the major portion of the total BP content of the CM was secreted by the polygonal astrocytes.

The cultures were used within 1 week of "purification" and at least $1 \mathrm{~d}$ after the medium change. After purification, cells in $200 \mathrm{ml}$ flasks were washed twice with serum-free BME (SF-BME) and incubated in $20 \mathrm{ml}$ of fresh SF-BME for $24 \mathrm{hr}$ at $37^{\circ} \mathrm{C}$. The medium was aspirated and replaced with $20 \mathrm{ml}$ of SF-BME containing $2 \mathrm{mg} / \mathrm{ml} \mathrm{BSA} \mathrm{(Sigma,}$ lot no. $122 \mathrm{~F}-0890$, which contained no $\mathrm{Sm}-\mathrm{C} / \mathrm{IGF}$ I by radioimmunoassay) and incubated at $37^{\circ} \mathrm{C}$. CM was collected after $48 \mathrm{hr}$ and stored frozen at $-20^{\circ} \mathrm{C}$. This $\mathrm{CM}$ was used for characterization studies. For studies of the time course of BP elaboration, astroglial cells were subplated into 48 -well tissue culture plates $\left(1 \mathrm{~cm}^{2}\right.$ growth area/well; Costar, Cambridge, MA), at cell densities of $0.12 \times 10^{6} \mathrm{cells} /$ well, in BME with $10 \%$ FCS, and cultured until confluence (usually for $48 \mathrm{hr}$ ). Cells were then washed twice with SF-BME, incubated in fresh SF-BME for $24 \mathrm{hr}$, and then in either SF-BME or SF-BME containing $2 \mathrm{mg} / \mathrm{ml} \mathrm{BSA}$ for an additional 0 ( $2 \mathrm{~min}), 6,12,18,24,36$, and $48 \mathrm{hr}$. CM was collected and stored frozen at $-20^{\circ} \mathrm{C}$.

${ }_{125} I$-Sm/IGF affinity cross-linking studies. A modification of the method described by Wilkins and D'Ercole (1985) was used to affinity crosslink ${ }^{125} \mathrm{I}-\mathrm{Sm} / \mathrm{IGFs}$ to binding proteins in astroglial CM. CM, either unconcentrated $(50 \mu \mathrm{l})$ or concentrated $[10 \mu \mathrm{l}$ of $20 \times \mathrm{CM}$, concentrated by centrifugation in Centricon microconcentrators (Amicon, Danvers, MA) with $10 \mathrm{~K} \mathrm{Da} M_{\mathrm{r}}$ cutoff membrane], was incubated for $30 \mathrm{~min}$ with ${ }^{125}$ I-Sm-C/IGF I, IGF II, or insulin $(250,000 \mathrm{cpm} /$ tube, $100 \mathrm{fmol})$ in $100 \mathrm{~mm}$ HEPES containing $12 \mathrm{M} \mathrm{NaCl}, 5 \mathrm{mM} \mathrm{KCl}, 1.2 \mathrm{~mm} \mathrm{MgSO}_{4}$, and $8 \mathrm{~mm}$ dextrose, $\mathrm{pH} 7.4$ (HEPES buffer) to a final reaction volume of $100 \mu \mathrm{l}$ at $4^{\circ} \mathrm{C}$, with or without varying concentrations of unlabeled peptides. Cross-linking was accomplished by the addition of $5 \mu \mathrm{l}$ of 10 mM disuccinimidyl suberate (DSS; Pierce Chemicals, Rockford, IL) dissolved in dimethyl sulfoxide (DMSO) to give a final concentration of $0.5 \mathrm{~mm}$ DSS, followed by incubation at room temperature for 10 min. The cross-linking reaction was stopped and the proteins were solubilized by the addition of $20 \mu \mathrm{l}$ of $5 \times$ gel sample buffer $(62.5 \mathrm{~mm}$ Tris$\mathrm{HCl}, \mathrm{pH} 8.8,5 \%$ SDS, $0.01 \%$ bromophenol blue, and $40 \%$ glycerol) with or without the reducing agent 2 -mercaptoethanol $(10 \%)$, and boiled for $3 \mathrm{~min}$

Affinity cross-linking of ${ }^{125}[-\mathrm{Sm}-\mathrm{C} / \mathrm{IGF}$ I to receptors on astroglial cells was performed as previously described (Han et al., 1987). Briefly, purified astroglial cells were plated on $35 \mathrm{~mm}$ tissue culture dishes and cultured to confluence. The medium was replaced with SF-BME and cultured for another $48 \mathrm{hr}$. The cells were washed with $100 \mathrm{~mm}$ HEPES buffer, $\mathrm{pH} 8.0$, with BSA $10 \mathrm{mg} / \mathrm{ml}$, and incubated with ${ }^{125} \mathrm{I}-\mathrm{Sm}-\mathrm{C} / \mathrm{IGF}$ I (4-5 $\times 10^{5} \mathrm{cpm} /$ dish) in fresh HEPES buffer, without or with varying concentrations of $\mathrm{BRL}-3 \mathrm{~A} \mathrm{BP}$ at $4^{\circ} \mathrm{C}$ for $16-18 \mathrm{hr}$. The incubation solution was then aspirated, and the cultures were washed 3 times with cold HEPES buffer, $\mathrm{pH} 7.4$, without BSA, to remove the unbound radiolabel. The ${ }^{125} \mathrm{I}-\mathrm{Sm}-\mathrm{C} / \mathrm{IGF}$ I that was bound to cell surface receptors was affinity cross-linked with $0.1 \mathrm{~m}$ DSS at $22^{\circ} \mathrm{C}$ for $10 \mathrm{~min}$. The reaction was stopped by aspiration of the DSS solution and addition of $1 \mathrm{ml}$ of $10 \mathrm{~mm}$ Tris-HCl. The cells were scraped from the bottom of the dish using a disposable plastic spatula, solubilized in $2 \%$ SDS, $12.5 \mathrm{~mm}$ Tris$\mathrm{HCl}, 0.002 \%$ bromophenol blue, $8 \%$ glycerol, and $100 \mathrm{~mm}$ dithiothrietol (DTT), and boiled for $5 \mathrm{~min}$.

The samples were then subjected to SDS-PAGE on 6-14\% linear gradient gels for CM BPs, and 3-14\% linear gradient gels for astroglial cell membrane receptors, using a Tris-glycine buffer, $\mathrm{pH} 8.0$, according to the method of Laemmli (1970). Gels were then fixed in $10 \%$ acetic acid and $30 \%$ methanol solution, washed, dried, and exposed to $x$-ray film (Kodak XAR or XRP) between 2 intensifying screens (Dupont Chemical, Wilmington, DE) at $-70^{\circ} \mathrm{C}$ for 3-7 d. The $M_{\mathrm{r}} \mathrm{s}$ of the standards used for SDS-PAGE were myosin $(200,000 \mathrm{Da})$, phosphorylase B $(97,400 \mathrm{Da})$, BSA $(68,000 \mathrm{Da})$, ovalbumin $(43,000 \mathrm{Da})$, alpha chymotrypsin $(25,700 \mathrm{Da})$, beta lactglobulin $(18,400 \mathrm{Da})$, and lysozyme (14,300 Da) (Bethesda Research Laboratories, Bethesda, MD).

Binding of ${ }^{125} I-S m-C / I G F I$ to binding proteins after transfer to nitrocellulose membrane. Concentrated $(20 \times)$ astroglial $\mathrm{CM}, 50 \mu \mathrm{l}$, was incubated in $10 \mu \mathrm{l}$ of gel sample buffer 5 times at $50^{\circ} \mathrm{C}$ for $1 \mathrm{hr}$ and the proteins separated on a 6-14\% linear gradient SDS-PAGE, as above. This was followed by electrophoretic transfer to nitrocellulose (NC) membrane (pore size, $0.45 \mu \mathrm{m}$; New England Nuclear, Cambridge, MA) on an electrophoretic blotting apparatus (Trans-Blot System; Bio-Rad, Richmond, CA) for $500 \mathrm{~V}$ hr in Tris-glycine-methanol buffer, $\mathrm{pH} 7.4$ After brief washing in this buffer, the NC membrane was air-dried for $30 \mathrm{~min}$, enclosed in a Micro-Seal plastic bag (Dazey, Industrial Airport, $\mathrm{KS}$ ), and incubated in $0.1 \mathrm{~m}$ HEPES buffer, $\mathrm{pH} 7.4$, containing $0.12 \mathrm{M}$ $\mathrm{NaCl}, 5 \mathrm{mM} \mathrm{KCl}, 1.2 \mathrm{mM} \mathrm{MgSO}_{4}, 8 \mathrm{~mm}$ dextrose, at room temperature for $1 \mathrm{hr}$ with constant shaking. This solution was replaced with fresh buffer containing ${ }^{125} \mathrm{I}-\mathrm{Sm}-\mathrm{C} / \mathrm{IGF} \mathrm{I}\left(0.5 \times 10^{6} \mathrm{cpm} / \mathrm{ml}\right)$ and incubated at room temperature for $1 \mathrm{hr}$. The NC membrane was removed from the bag and washed thoroughly with Tris-saline buffer containing $0.02 \%$ Nonidet-P 40 (Sigma) for $2 \mathrm{hr}$, with several changes of wash buffer, until the buffer was devoid of radiolabel. The NC membrane was airdried for $30 \mathrm{~min}$ and exposed to $\mathrm{x}$-ray film (Kodak XRP-5) at $-70^{\circ} \mathrm{C}$ for 4-8 hr. A similar technique has been used to analyze Sm/IGF BPs in human serum (Hossenlopp et al., 1986).

Immunoprecipitation of affinity-labeled BPs. Ten microliters of $20 \times$ concentrated CM in $10 \mathrm{mM}$ HEPES buffer was affinity-labeled with ${ }^{125} \mathrm{I}$ Sm-C/IGF I, as described above (final reaction vol, $100 \mu \mathrm{l}$ ). To this solution, $25 \mu \mathrm{l}$ of BRL-3A antibodies ( $\mathrm{F}$ or $\mathrm{P}$ ) or control preimmune antibody $(C)$ was added to achieve a final dilution of $1: 100$ and incubated 


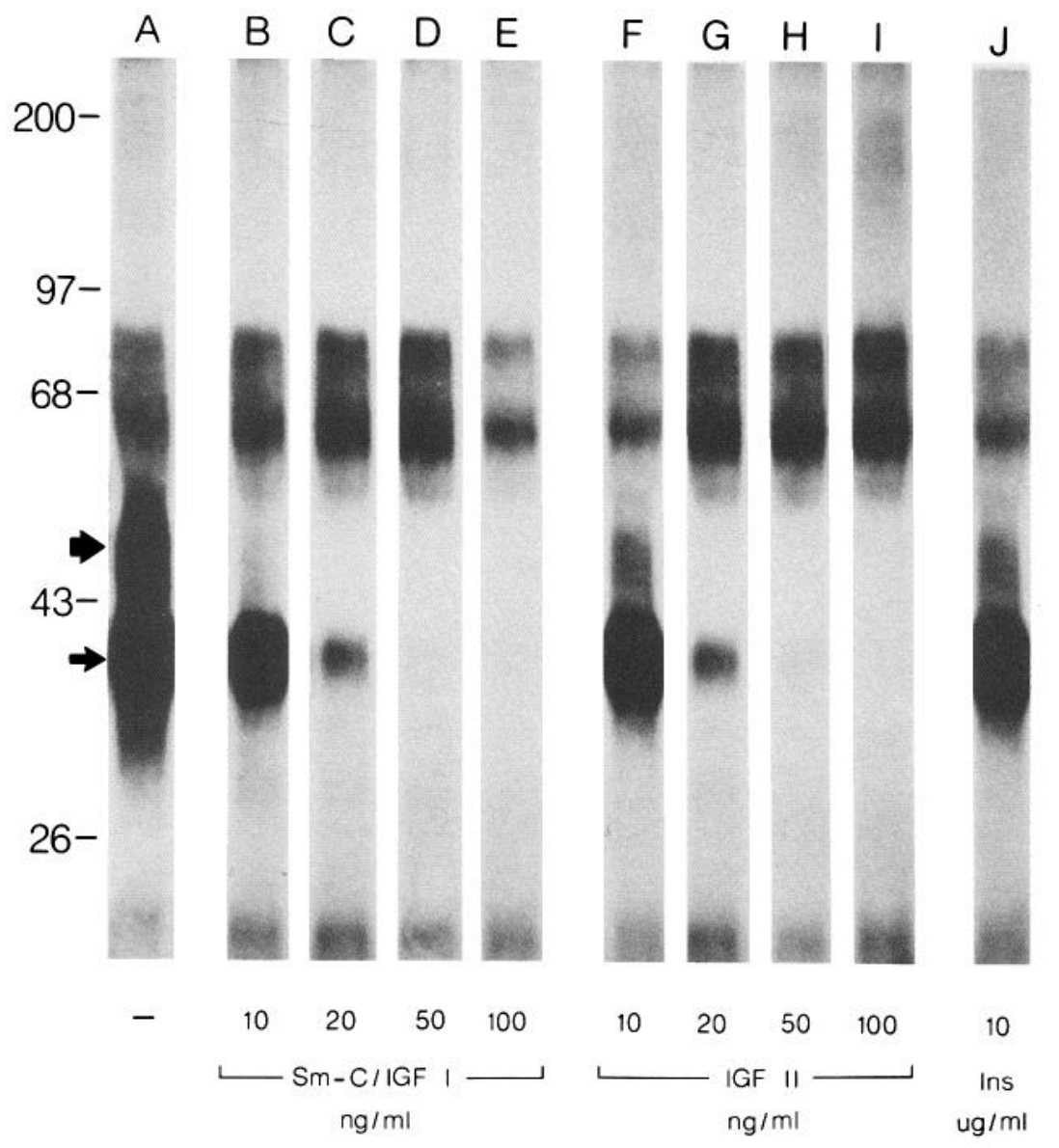

Figure 1. Electrophoretic analysis and autoradiography of ${ }^{125} \mathrm{I}-\mathrm{Sm}-\mathrm{C} / \mathrm{IGF}$ I BP complexes in astroglial CM cross-linked in the absence and presence of unlabeled Sm-C/IGF I, IGF II, or insulin. Left, indication of the migration of $M_{\mathrm{r}}$ markers $\left(\times 10^{-3}\right)$. The $45 \mathrm{~K}$ complex (large arrow) and $40 \mathrm{~K}$ complex (small arrow) are diminished in intensity or obliterated in the presence of unlabeled Sm-C/IGF I $(B-E)$ and IGF II $(F-I)$. Unlabeled insulin at $10 \mu \mathrm{g} / \mathrm{ml}$ diminished the intensity of the $45 \mathrm{~K}$ complex but not the $40 \mathrm{~K}$ complex $(J)$. A radiolabeled band of approximately $68 \mathrm{~K}$ observed in each lane represents a nonspecific binding of ${ }^{125} \mathrm{I}-\mathrm{Sm}-\mathrm{C} / \mathrm{IGF}$ I to albumin in the CM. at $4^{\circ} \mathrm{C}$ for $18-20 \mathrm{hr}$ (the antibodies were partially purified by precipitating antisera with $30 \%$ ammonium sulfate, and followed by dialysis and lyophilization). Sheep anti-rabbit antiserum (15 $\mu \mathrm{l}$; Wellcome Laboratories, Beckinham, UK) was added to each sample and incubated for another $2 \mathrm{hr}$ at room temperature. Finally, $10 \mu \mathrm{l}$ of normal rabbit serum was added to each sample and incubated for $2 \mathrm{hr}$ at $4^{\circ} \mathrm{C}$. Immunoprecipitates were collected by centrifugation in a microcentrifuge for $5 \mathrm{~min}$ and washed twice with phosphate buffer, $\mathrm{pH}$ 7.4. Immunoprecipitates were solubilized in $50 \mu \mathrm{l}$ gel sample buffer $(62.5 \mathrm{~mm}$ Tris$\mathrm{HCl}, \mathrm{pH} 6.8,1 \%$ SDS, $8 \%$ glycerol, $0.1 \%$ bromophenol blue, and $2 \%$ 2 -mercaptoethanol) and boiled for $3 \mathrm{~min}$. Samples were subjected to $6-14 \%$ linear gradient SDS-PAGE and the gels were fixed, dried, and autoradiographed as described above.

Astroglial receptor binding studies. Binding studies were performed on plated astroglial cells as previously described (Han et al., 1987). Briefly, astroglial cells were plated on 48-well tissue culture plates and cultured until confluence. They were then incubated in SF-BME for 48 $\mathrm{hr}$ prior to incubation with ${ }^{125} \mathrm{I}-\mathrm{Sm}-\mathrm{C} / \mathrm{IGF}$ I $(50,000 \mathrm{cpm} / \mathrm{well} ; 20 \mathrm{fmol})$ in $0.1 \mathrm{~m}$ HEPES binding buffer, $\mathrm{pH} 8.0$, in the presence of graded concentrations of BRL-3A BP $(5 \mathrm{ng} / \mathrm{ml}$ to $1 \mu \mathrm{g} / \mathrm{ml})$ for $4 \mathrm{hr}$ at $4^{\circ} \mathrm{C}$. Nonspecific binding was determined as binding in the presence of an excess of unlabeled Sm-C/IGF I $(10 \mu \mathrm{g} / \mathrm{ml})$. Binding was terminated by aspiration of the incubating solution and washing the cultures thoroughly with cold PBS 3 times. The cells were solubilized with $0.1 \mathrm{~N}$ $\mathrm{NaOH}$ and $1 \%$ SDS for $15 \mathrm{~min}$ at room temperature, and the cell lysate was transferred to test tubes. The cell associated radioactivity was then determined in a gamma spectrometer (Hewlett-Packard, Corvallis, OR).

${ }^{3} \mathrm{H}$-Thymidine incorporation studies. The effects of BRL-3A BP on the mitogenic action of Sm-C/IGF I on astroglial cells was determined by ${ }^{3} \mathrm{H}$-thymidine incorporation assay, as previously described (Han et al., 1987). Briefly, astroglial cells were plated on 48-well tissue culture plates and cultured to subconfluence (usually $48 \mathrm{hr}$ ). They were then incubated in SF-BME for $48 \mathrm{hr}$ and exposed to $25 \mathrm{ng} / \mathrm{ml} \mathrm{Sm-C/IGF} \mathrm{I}$ with varying concentrations of the BRL-3A BP $(0-1 \mu \mathrm{g} / \mathrm{ml})$. After incubation for $22 \mathrm{hr},{ }^{3} \mathrm{H}$-thymidine $(0.5 \mu \mathrm{Ci} /$ well; New England Nuclear) was added to the cultures and the incubation was continued for another $2 \mathrm{hr}$. The reaction was stopped by aspiration of the incubating solution and washing with cold $\left(4^{\circ} \mathrm{C}\right)$ PBS 3 times. The cultures were then incubated with $5 \%$ trichloracetic acid (TCA) at $4^{\circ} \mathrm{C}$ for $20 \mathrm{~min}$. The TCA solution was aspirated and the cultures were washed again with fresh $5 \%$ TCA. After removal of the TCA solution, the cultures were solubilized in $0.1 \mathrm{~N} \mathrm{NaOH}$ and $1 \%$ SDS. The resulting solution was added to $10 \mathrm{ml}$ of complete counting cocktail (Research Products International, Elk Grove Village, IL) and counted in a scintillation counter (LKB Instruments, Gaithersburg, MD).

\section{Results}

Affinity-labeled Sm/IGF-BP complexes in astroglial CM

When concentrated astroglial CM was affinity-labeled with ${ }^{125} \mathrm{I}$ Sm-C/IGF I and analyzed by SDS-PAGE, 2 species of radiolabeled Sm-C/IGF I-BP complexes, with $M_{\mathrm{r}} \mathrm{s}$ of $45 \mathrm{~K}$ and $40 \mathrm{~K}$ were observed under reducing conditions (Fig. 1). Under nonreducing conditions, 2 similar-sized species were observed, but the resolution of the 2 bands was inferior (not shown). These bands were judged to represent specific Sm/IGF-BP complexes because their intensity was diminished or obliterated when either unlabeled Sm-C/IGF I or IGF II $(50 \mathrm{ng} / \mathrm{ml})$ was present during the incubation. The $45 \mathrm{~K}$ complex could be lessened in intensity by as little as $5 \mathrm{ng} / \mathrm{ml} \mathrm{Sm-C/IGF} \mathrm{I} \mathrm{(not} \mathrm{shown)} \mathrm{or} 10 \mathrm{ng} / \mathrm{ml} \mathrm{IGF}$ II, and obliterated by $20 \mathrm{ng} / \mathrm{ml} \mathrm{Sm}-\mathrm{C} / \mathrm{IGF}$ I or $50 \mathrm{ng} / \mathrm{ml} \mathrm{IGF}$ II. Very high concentrations of insulin $(10 \mu \mathrm{g} / \mathrm{ml})$ could also compete for ${ }^{125} \mathrm{I}-\mathrm{Sm}-\mathrm{C} / \mathrm{IGF}$ I binding. Approximately 10-fold higher concentrations of either Sm-C/IGF I or IGF II were required to compete for the binding in the $40 \mathrm{~K}$ complex, while $10 \mu \mathrm{g} / \mathrm{ml}$ of insulin did not appear to compete for this binding. 
Figure 2. Electrophoretic analysis and autoradiography of ${ }^{125}$ I-IGF II BP complexes in astroglial CM cross-linked in the absence and presence of unlabeled IGF II, Sm-C/IGF I, or insulin. Left, indication of the migration of $M_{\mathrm{r}}$ markers $\left(\times 10^{-3}\right)$. The $45 \mathrm{~K}$ complex (large arrow) and $40 \mathrm{~K}$ complex (small arrow) are diminished in intensity in the presence of unlabeled IGF II $(B-E)$ and Sm$\mathrm{C} / \mathrm{IGF}$ I $(F-I)$. Unlabeled insulin at 10 $\mu \mathrm{g} / \mathrm{ml}$ diminished the intensity of the $45 \mathrm{~K}$ complex, but not of the $40 \mathrm{~K}$ complex $(J)$. A radiolabeled band of approximately $68 \mathrm{~K}$ observed in each lane represents a nonspecific binding of ${ }^{125} \mathrm{I}-$ $\mathrm{Sm}-\mathrm{C} / \mathrm{IGF}$ I to albumin in the CM.
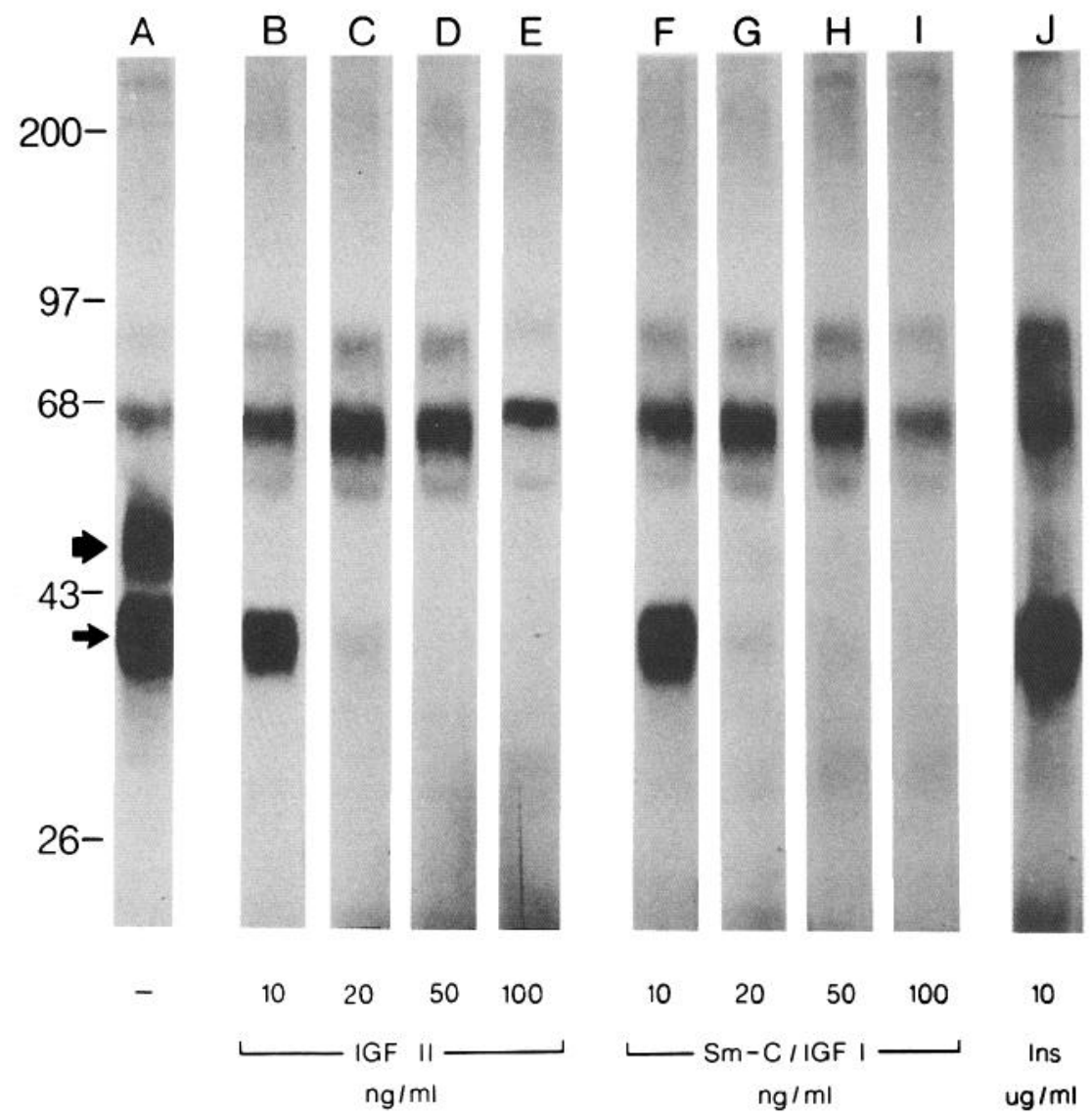

\section{Studies of BP secretion}

$\mathrm{CM}$ collected by incubation of astroglial cells in SF-BME for $48 \mathrm{hr}$ resulted in a decrease in the intensity of radiolabeled complexes, as compared to CM collected by incubation of astroglia with SF-BME containing BSA (data not shown). The latter finding suggests that BP synthesis is dependent on an exogenous protein source. To study the time course of secretion of the BPs, astroglial cultures were serum-starved for $48 \mathrm{hr}$, then incubated with SF-BME with BSA and CM collected at 6 hourly intervals. When $\mathrm{CM}$ were affinity cross-linked to ${ }^{125} \mathrm{I}-\mathrm{Sm}$-C/IGF I, both complexes were detectable at $6 \mathrm{hr}$, and progressively increased in apparent abundance. The $40 \mathrm{~K}$ complex was more intensely labeled than the $45 \mathrm{~K}$ complex at each time, suggesting that it is more rapidly synthesized and therefore more abundant. Incubation with hGH did not alter the apparent rate of synthesis of either BP.

\section{Biochemical characteristics of the BPs}

To further characterize these BPs, they were subjected to a variety of physicochemical treatments prior to affinity crosslinking with ${ }^{125} \mathrm{I}-\mathrm{Sm}-\mathrm{C} / \mathrm{IGF}$ I. Heating of $\mathrm{CM}$ to $56^{\circ} \mathrm{C}$ for $2 \mathrm{hr}$, freezing at $-20^{\circ} \mathrm{C}$ for up to 3 months, acidification (to $\mathrm{pH} 2$ ), alkalinization (to $\mathrm{pH} 10$ ), or incubation with endoglycosidase- $\mathrm{F}$ (1-100 U/ml; New England Nuclear) did not have apparent effects on ${ }^{125} \mathrm{I}-\mathrm{Sm}-\mathrm{C} / \mathrm{IGF}$ I binding or on the size of the binding moieties. However, heating at temperatures of $80^{\circ} \mathrm{C}$ or higher for $5 \mathrm{~min}$, reduction with 2-mercaptoethanol, and mild pro- 


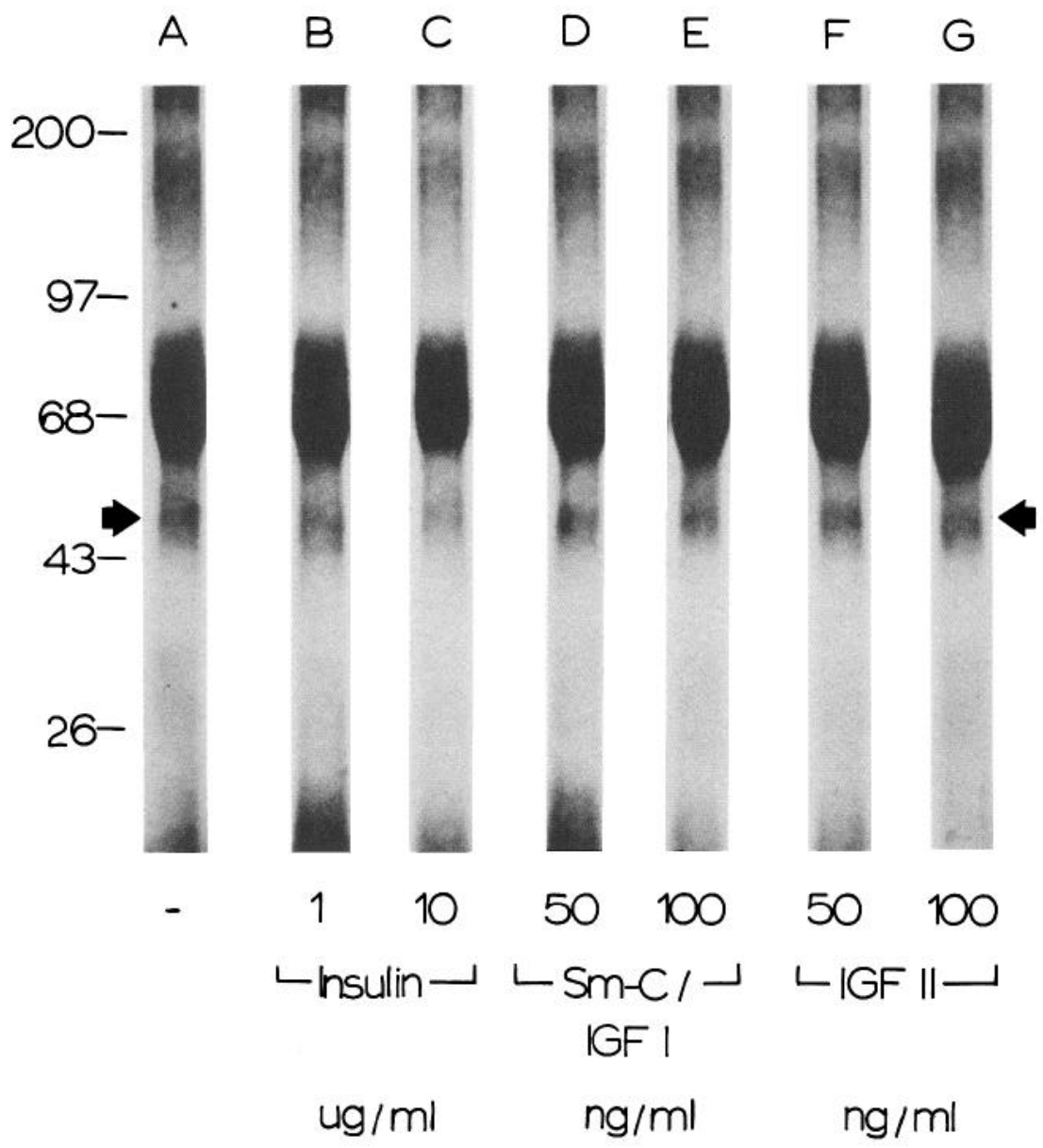

Figure 3. Electrophoretic analysis and autoradiography of ${ }^{125} \mathrm{I}$-insulin $\mathrm{BP}$ complexes in astroglial CM cross-linked in the absence and presence of unlabeled insulin $(B, C)$, unlabeled $\mathrm{Sm}-\mathrm{C} /$ IGF I $(D, E)$ and unlabeled IGF II $(F$, $G)$. Left, indication of the migration of $M_{\mathrm{r}}$ markers $\left(\times 10^{-3}\right)$. A single radiolabeled band of $45 \mathrm{~K}$ (large arrow) is observed and is diminished in intensity only by a high concentration of unlabeled insulin $(10 \mu \mathrm{g} / \mathrm{ml} ; C)$. Sm-C/IGF $\mathrm{I}$ and IGF II in the concentrations used have no apparent effect. teolytic treatment (e.g., $0.001 \%$ trypsin for $30 \mathrm{~min}$ ) destroyed binding activity. These results are consistent with $\mathrm{pH}$-stable, nonglycosylated proteins, which contain interchain disulfide bonds that are essential for binding.

\section{Binding of ${ }^{125} I-S m-C / I G F I$ to BPs transferred to nitrocellulose membrane}

After transfer of electrophoretically resolved astroglial CM to nitrocellulose membrane and binding with ${ }^{125} \mathrm{I}-\mathrm{Sm}-\mathrm{C} / \mathrm{IGF} \mathrm{I}, 2$ radiolabeled bands with $M_{\mathrm{r}} \mathrm{s}$ of $38-40 \mathrm{~K}$ and $33-35 \mathrm{~K}$ were observed. These bands appear to represent the 45 and $43 \mathrm{~K}$ BP complexes that were observed when conditioned medium was affinity cross-linked to ${ }^{125} \mathrm{I}-\mathrm{Sm}-\mathrm{C} / \mathrm{IGF}$ I prior to separation on SDS-PAGE (Fig. 4). Because the $M_{\mathrm{r}} \mathrm{s}$ of the BPs thus identified correspond well with those of the affinity-labeled complexes minus the $M_{\mathrm{r}}$ of the radiolabeled ligand $(45 \mathrm{~K}-7 \mathrm{~K}=38 \mathrm{~K}$, and $40 \mathrm{~K}-7 \mathrm{~K}=33 \mathrm{~K}$ ), these findings are consistent with the binding of a single molecule of $\mathrm{Sm} / \mathrm{IGF}$ to each BP molecule.

\section{Relationship between astroglial BPs and BRL-3A BP}

Affinity labeling of the BP purified from BRL-3A cells with ${ }^{125} \mathrm{I}_{-}$ Sm-C/IGF I revealed a single band of $M_{\mathrm{r}} 40 \mathrm{~K}$, which could be obliterated by incubation with $100 \mathrm{ng} / \mathrm{ml}$ of unlabeled Sm-C/ IGF I (Fig. 7). When astroglial BP was affinity-labeled with ${ }^{125} I-$ Sm-C/IGF I and immunoprecipitated with antisera $F$ and $P$, which were raised against BRL-3A BP, a single band of $M_{\mathrm{r}} 40 \mathrm{~K}$ was observed (Fig. 5). A control preimmune rabbit serum (C) did not result in positive immunoprecipitation. These results demonstrate that the BRL-3A BP is immunologically similar to the rat astroglial $\mathrm{BP}$ in the $40 \mathrm{~K}$ complex.

Effects of BRL-3A BP on the mitogenic action of Sm-C/IGF I Addition of $25 \mathrm{ng} / \mathrm{ml} \mathrm{Sm-C/IGF} \mathrm{I} \mathrm{stimulates}{ }^{3} \mathrm{H}$-thymidine incorporation of astroglial cells 4-fold above the basal conditions. ${ }^{3} \mathrm{H}$-Thymidine incorporation could be reduced by purified BRL-3A BP in a dose-dependent manner (Fig. 6). Addition of BRL-3A BP to astroglial cells in the absence of Sm-C/IGF I did not alter the basal ${ }^{3} \mathrm{H}$-thymidine incorporation, suggesting that the effect of the BP is specific to the mitogenic action of Sm-C/ IGF I on astroglia.

To determine whether the effect of BP on the mitogenic action of $\mathrm{Sm}-\mathrm{C} / \mathrm{IGF}$ I was due to competition with the $\mathrm{Sm} / \mathrm{IGF}$ receptors for the peptide, increasing concentrations of the BP were added to a constant concentration of radiolabeled Sm-C/IGF I. The BRL-3A BP inhibited ${ }^{125} \mathrm{I}-\mathrm{Sm}-\mathrm{C} / \mathrm{IGF}$ I binding to astroglial cells in a dose-dependent manner (Fig. 7). Moreover, the BP concentration causing half-maximal binding inhibition $(77 \mathrm{ng} /$ $\mathrm{ml})$ was nearly identical to the concentration resulting in halfmaximal inhibition of mitogenic response to Sm-C/IGF I (80 $\mathrm{ng} / \mathrm{ml}$ ). These findings strongly suggest that the BRL-3A BP inhibits the mitogenic actions of Sm-C/IGF I by competing with the receptor for the ligand.

The latter conclusion is further supported by the affinity crosslinking studies. Affinity-labeling of the astroglial cell surface 


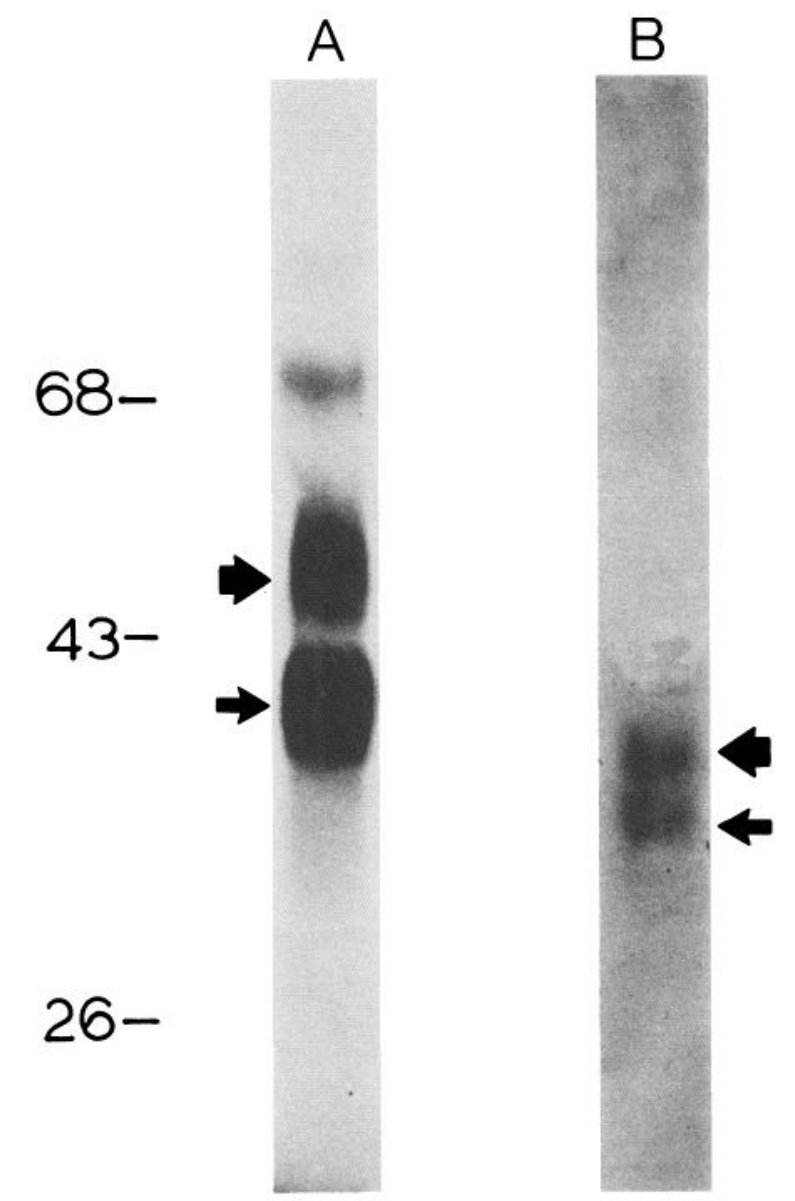

Figure 4. Identification of astroglial Sm/IGF BPs by transfer to nitrocellulose membrane following electrophoresis and binding to ${ }^{125} \mathrm{I}-\mathrm{Sm}$ C/IGF I $(B)$. BPs identified by the affinity cross-linking method are shown in $A$ for comparison. Left, indication of migration of $M_{\mathrm{r}}$ markers $\left(\times 10^{-3}\right)$.

receptors with ${ }^{125} \mathrm{I}-\mathrm{Sm}-\mathrm{C} / \mathrm{IGF} \mathrm{I}$ and analysis on SDS-PAGE under reducing conditions (Fig. 8) showed radiolabeled bands of $M_{\mathrm{r}} 130 \mathrm{~K}$ (alpha subunit of the type I Sm/IGF receptor), $M_{\mathrm{r}}$ $260 \mathrm{~K}$ (type II Sm/IGF receptor) and $M_{\mathrm{r}}>300 \mathrm{~K}$ (unreduced type I receptor). Specificity of binding of the radiolabel to these receptors has been shown previously (Han et al., 1987). The addition of increasing concentrations of BRL-3A BP to the binding buffer prior to cross-linking diminished the intensity of all 3 bands, and at BP concentration of $1 \mu \mathrm{g} / \mathrm{ml}$, radiolabeled receptor complexes were not observed (Fig. 8). The reduction in the intensity of radiolabeled bands in the presence of increasing concentrations of BP correlated well with the inhibition of specific binding observed in the binding studies (Fig. 7). These results indicate that the $\mathrm{BP}$ binds $\mathrm{Sm}-\mathrm{C} / \mathrm{IGF} \mathrm{I}$ and prevents binding of Sm-C/IGF I to its cell surface receptors. Sm-C/IGF $\mathrm{I}$ is thus rendered biologically inactive. Similar findings were observed with radiolabeled IGF II (data not shown).

\section{Discussion}

By using DSS, we have covalently cross-linked radiolabeled Sm/ IGFs to specific binding moieties in CM from rat astroglial cells. Our evidence suggests that each is a pH-stable, nonglycosylated protein with interchain disulfide linkages capable of binding one molecule of either Sm-C/IGF I or IGF II with near-equal affin- ity. The BPs in these cross-linked complexes appear to have $M_{\mathrm{r}} \mathrm{s}$ of $38-40 \mathrm{~K}$ and $33-35 \mathrm{~K} \mathrm{Da}$, respectively.

Both Sm-C/IGF I and IGF II (or MSA) appeared equipotent in competing for the binding to each of the BPs, suggesting that the Sm/IGFs share the same BPs. This is in agreement with our previous findings of rat serum BPs (D'Ercole and Wilkins, 1984), as well as those of Moses et al. (1976). That the 45K complex was about 5 -fold more sensitive to competition by the $\mathrm{Sm} / \mathrm{IGFs}$ than the $40 \mathrm{~K}$ complex may reflect either differences in affinity or in the abundance of each BP. The techniques used do not distinguish between these possibilities.

Several lines of evidence indicate that the 45 and the $40 \mathrm{~K}$ complexes represent distinct BPs: (1) The $40 \mathrm{~K}$ cross-linked complex, but not the $45 \mathrm{~K}$ complex, is recognized by antibodies against the BRL-3A BP. (2) The BP in the $45 \mathrm{~K}$ complex recognizes insulin weakly, while that in the $40 \mathrm{~K}$ complex does not. (3) Because endoglycosidase-F did not decrease the size of either complex, it is. unlikely that the BP in the $45 \mathrm{~K}$ complex is a $N$-glycosylated form of the $40 \mathrm{~K}$ species. And (4), our finding that the 2 BPs could be separated electrophoretically prior to binding with a radiolabeled ligand indicates that the 2 complexes do not represent the same BP bound to different numbers of $\mathrm{Sm} / \mathrm{IGF}$ molecules.

$\mathrm{Sm} / \mathrm{IGF}$ BPs of sizes similar to those observed here have been identified in rat serum both by column chromatography (Moses et al., 1976) and affinity cross-linking (D'Ercole and Wilkins, 1984). The $40 \mathrm{~K}$ complex we observed appears similar or identical to the non-GH-dependent $40 \mathrm{~K}$ complex observed in rat serum. This BP was recognized by antibodies raised against a 32K BP purified from BRL-3A cells (Mottola et al., 1986). Romanus et al. (1986) also purified a BP of near-identical size (33K) from BRL-3A CM, and showed that antibodies raised against it recognized the $40 \mathrm{~K}$ non- $\mathrm{GH}$-dependent $\mathrm{BP}$ complex in rat serum. Our finding that the $40 \mathrm{~K}$ complex elaborated by astroglial cells is not increased in apparent abundance by incubation with GH further supports our conclusion that the 33$35 \mathrm{~K} \mathrm{BP}$ in this complex is the same or very similar to the bloodborne non-GH-dependent BP.

The identity of the $45 \mathrm{~K}$ complex is less clear. We have observed a similarly sized (49K) Sm/IGF-BP complex by affinity cross-linking of rat serum (D'Ercole and Wilkins, 1984). Our finding that the BP represented in this species can bind insulin (albeit with low affinity) argues that this BP is unique, because, to our knowledge, no other $\mathrm{Sm} / \mathrm{IGF}$ BP has been reported as recognizing insulin even at high concentrations. Gjedde (1967), however, has reported that insulin binds to cat serum proteins that migrate at a similar molecular size on open-bed columns. The very low apparent affinity of the BP in the $45 \mathrm{~K}$ complex makes it unlikely to function as a circulating carrier of insulin.

The tissue culture technique we used results in a relatively pure $(>90 \%)$ population of polygonal astroglial cells by morphological and immunocytochemical criteria (McCarthy and de Vellis, 1980), and thus provides evidence that the BPs characterized in this study were synthesized by these cells. However, we cannot exclude the contribution of other nonastrocytic cells, e.g., fibroblasts, oligodendrocytes, and ependymal cells, which form less than $5 \%$ of the cells. The confirmation of the presence of cell types that produce these BPs awaits in situ hybridization analysis with specific IGF BP cDNA probes. Further evidence of synthesis comes from the findings that there is an apparent reduction in BP following serum starvation, and an apparent progressive increase in BP when cells are incubated in SF-BME 


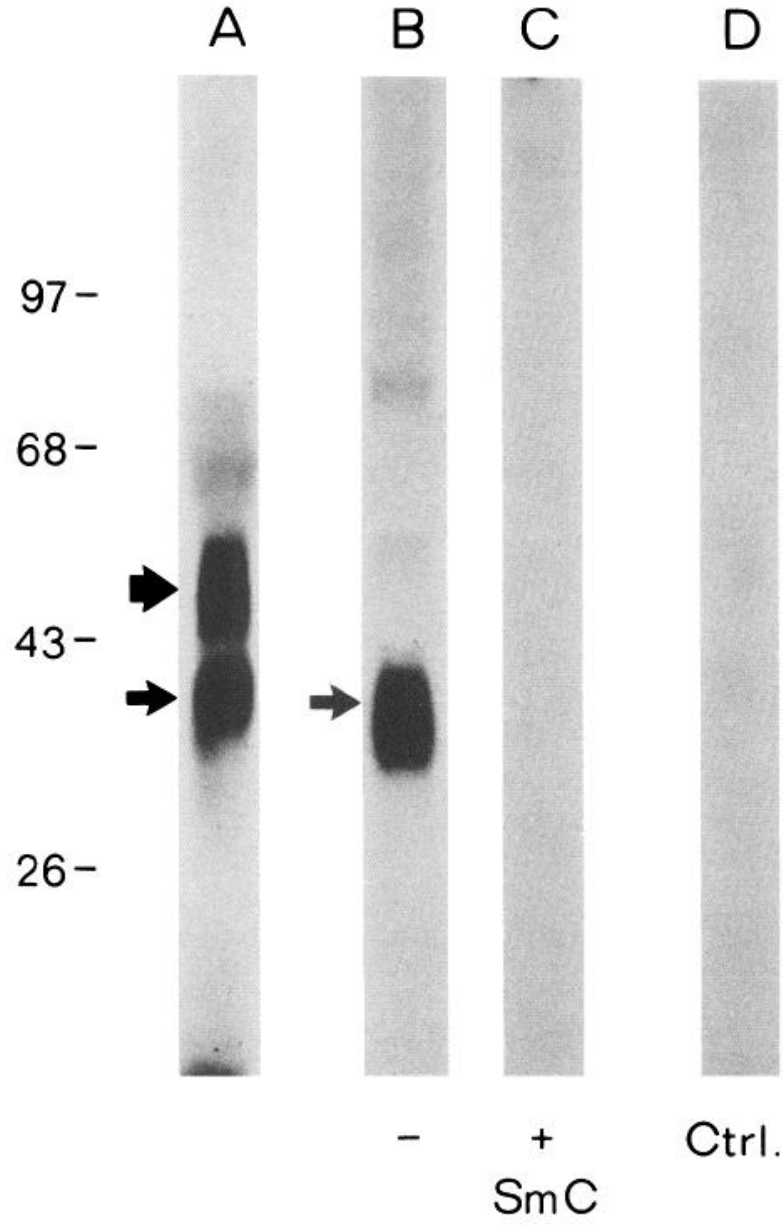

with BSA. Our findings agree with those of Binoux et al. (1981), who found that similarly sized BPs (as judged by open-bed gel chromatography) were synthesized by mixed neural cells in culture. On the basis of the affinity of BPs to IGFs and insulin, it

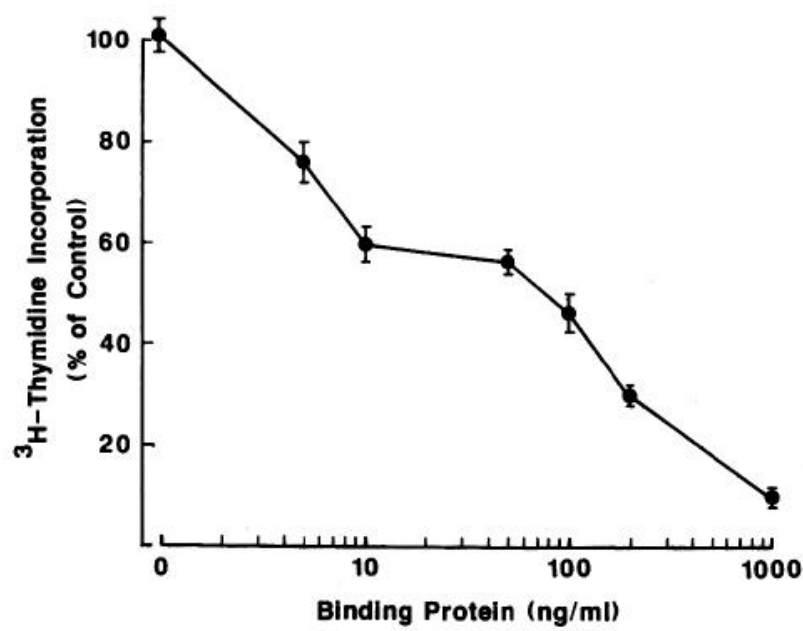

Figure 6. Reduction of ${ }^{3} \mathrm{H}$-thymidine incorporation of astroglial cells in response to Sm-C/IGF I $(25 \mathrm{ng} / \mathrm{ml})$ in the presence of increasing concentrations of BRL-3A BP. Each point is a mean \pm SEM of 6 replicates. $\mathrm{Sm}$-C/IGF I, $25 \mathrm{ng} / \mathrm{ml}$, increases ${ }^{3} \mathrm{H}$-thymidine incorporation 4 -fold under control conditions. The presence of increasing concentrations of BRL-3A BP in the absence of Sm-C/IGF I does not alter basal ${ }^{3} \mathrm{H}$-thymidine incorporation of astroglial cells (data not shown). The concentration of BRL-3A BP that caused half-maximal reduction of ${ }^{3} \mathrm{H}$-thymidine incorporation of astroglia was $80 \mathrm{ng} / \mathrm{ml}$.

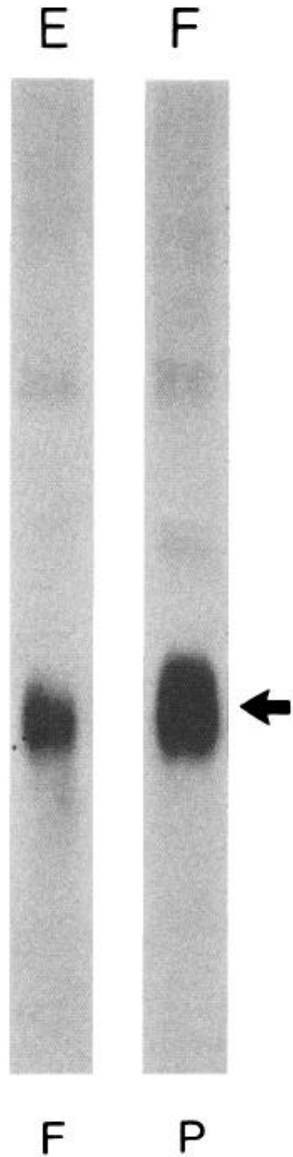

Figure 5. Electrophoretic analysis and autoradiography of the cross-linked ${ }^{125} \mathrm{I}$ Sm-C/IGF I BRL-3A BP complexes in the absence $(B)$ and presence of $100 \mathrm{ng} /$ $\mathrm{ml}$ unlabeled Sm-C/IGF I $(C)$. Binding protein complexes in astroglial $\mathrm{CM}$ is shown in $A$ for comparison. Electrophoretic analysis and autoradiography of ${ }^{125} \mathrm{I}-\mathrm{Sm}-\mathrm{C} / \mathrm{IGF}$ I BP complexes in astroglial CM immunoprecipitated with preimmune serum $\mathrm{C}(D)$ and antibodies $F$ and $P$ raised against BRL-3A BP $(E$, $F)$. Left, indication of migration of $M_{\mathrm{r}}$ markers $\left(\times 10^{-3}\right)$.

is possible that the $45 \mathrm{~K}$ complex, and not the $40 \mathrm{~K}$ complex, could be derived by limited proteolysis of the IGF receptor(s). Recently, Kiess et al. (1987), using immunologic and affinity cross-linking techniques, have shown that type II IGF receptor

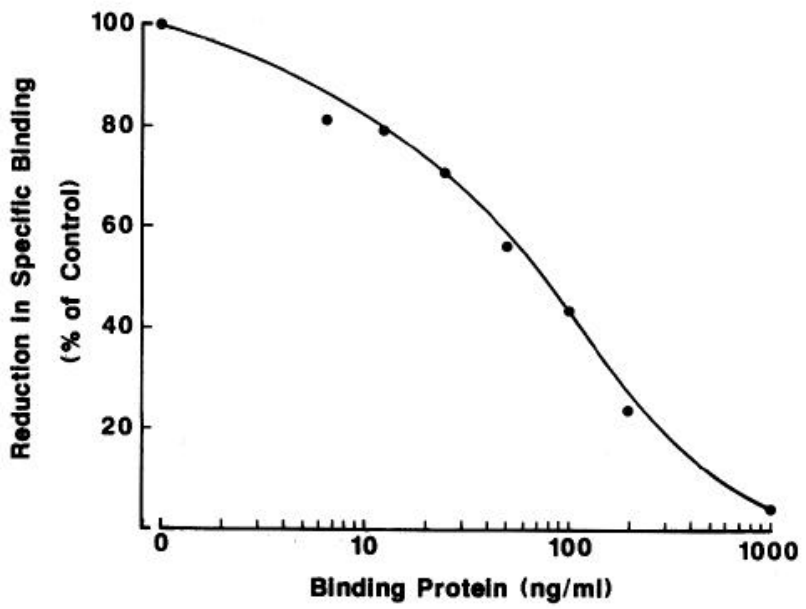

Figure 7. Competition for ${ }^{125} \mathrm{I}-\mathrm{Sm}-\mathrm{C} / \mathrm{IGF} \mathrm{I}$ binding to astroglial cells by increasing concentrations of BRL-3A BP. Nonspecific binding is binding in the presence of $10 \mu \mathrm{g} / \mathrm{ml}$ of unlabeled Sm-C/IGF I. Each point is a mean of 3 replicates. Maximum specific binding of ${ }^{125} \mathrm{I}-\mathrm{Sm}$ $\mathrm{C} / \mathrm{IGF}$ I to astroglial cells under control conditions (absence of BRL3 A BP) is approximately $10 \%$. The concentration of BRL-3A BP that caused half-maximal reduction of specific binding to astroglial cells was $77 \mathrm{ng} / \mathrm{ml}$. 


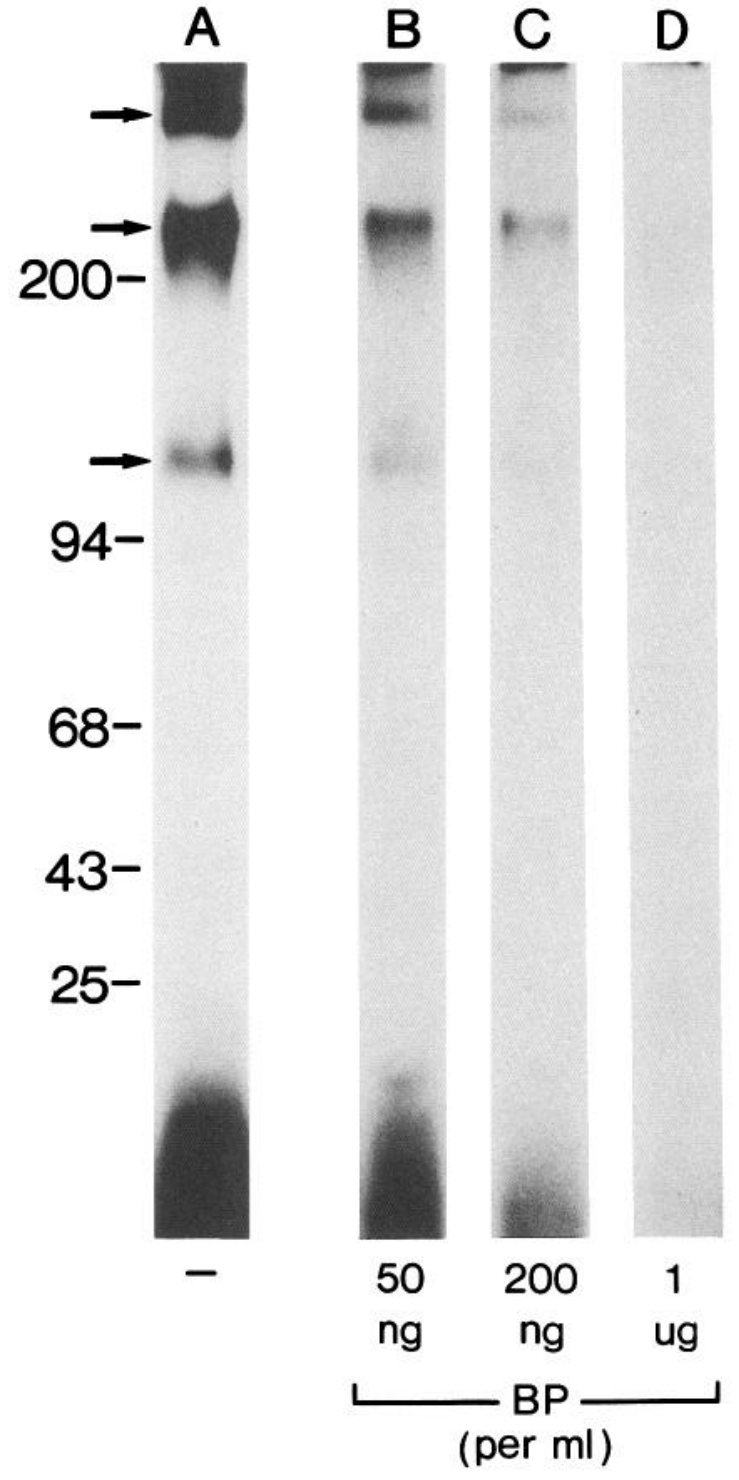

Figure 8. Electrophoretic analysis and autoradiography of affinity crosslinked ${ }^{125} \mathrm{I}-\mathrm{Sm}-\mathrm{C} / \mathrm{IGF}$ I bound astroglial cell surface receptors in the absence $(A)$ and presence $(B-D)$ of increasing concentrations of BRL3A BP (under reducing conditions). Left, indication of migration of $M_{\mathrm{r}}$ markers $\left(\times 10^{-3}\right)$. Arrows indicate affinity-labeled cell surface receptors.

can be detected by radioimmunoassay in the serum of rats. The level of type II receptor appears to be developmentally regulated. The sizes of the binding moieties are 210 and $240 \mathrm{kDa}$ under nonreduced and reduced conditions, respectively, and, therefore, are consistent with the sizes of the cell surface receptors under similar conditions. However, they are different from the sizes of the astroglial BPs described in this study.

Our data clearly demonstrate that addition of the BRL-3A $\mathrm{BP}$ to astroglia inhibits the action of Sm-C/IGF I by preventing $\mathrm{Sm}-\mathrm{C} / \mathrm{IGF}$ I binding to its cell surface receptors. Because this BP is similar to the $33 \mathrm{~K}$ species elaborated by astroglia, we assume that the latter would exert the same effect. Other influences of BP, however, seem possible. Elgin et al. (1987) have recently shown that a $35 \mathrm{~K}$ BP purified from human amniotic fluid can potentiate the mitogenic action of Sm-C/IGF I in cultured fibroblasts, possibly by delivering Sm-C/IGF I to its cell surface receptors. We have shown that human fibroblasts secrete a BP of approximately $35 \mathrm{~K}$ Da that associates with the cell surface and modulates the abundance of Sm-C/IGF I on the cell surface, including Sm-C/IGF I receptor binding (Clemmons et al., 1986). Using identical procedures, however, we did not observe rat astroglial BPs to be associated with the astroglial cell surface (unpublished observation). It seems possible that BPs that are secreted into the media have different effects than those capable of associating with the cell surface.

Herein, we have shown that neonatal rat astroglia secrete binding proteins that may modulate the biologic actions of $\mathrm{Sm} /$ IGFs. Binoux et al. (1981) have shown that pituitary and brain explants produce $\mathrm{Sm} / \mathrm{IGFs}$. Specific $\mathrm{Sm} / \mathrm{IGF}$ receptors have been demonstrated on neuronal (Burgess et al., 1987) and glial (Han et al., 1987) cells, and astroglia and oligodendroglia have been shown to respond to the mitogenic actions of Sm/IGFs (McMorris et al., 1986; Han et al., 1987). Taken together, these data point to a role for the Sm/IGFs in the development of glial cells. The present study is consistent with this hypothesis and suggests that the regulation of growth of glial cells may involve a complex mechanism of interactions between Sm/IGFs, their receptors and BPs.

\section{References}

Atkison, P. R., E. R. Weidman, B. Bhaumick, and R. M. Bala (1980) Release of somatomedin-like activity by cultured WI-38 human fibroblasts. Endocrinology 106: 2006-2012.

Bala, R. M., C. Wright, A. Bardai, and G. R. Smith (1978) Somatomedin bioactivity in serum and amniotic fluid during pregnancy. $J$. Clin. Endocrinol. Metab. 46: 649-652.

Binoux, M., P. Hossenlopp, C. Lassare, and D. Seurin (1980) Somatomedin production by rat liver in organ culture. I. Validity of technique. Influence of the released material on cartilage sulfation. Effects of growth hormone and insulin. Acta Endocrinol. (Copenh.) 93: 7382 .

Binoux, M., L. Hossenlopp, L. Lassarre, and S. Hardouin (1981) Production of insulin-like growth factors and their carriers by rat pituitary gland and brain explants in culture. FEBS Lett. 124: 178-184.

Burgess, S. K., S. Jacobs, P. Cuatrecasas, and N. Sayhoun (1987) Characterization of a neuronal subtype of insulin-like growth factor I receptor. J. Biol. Chem. 262: 1618-1622.

Chochinov, R. H., I. K. Mariz, A. S. Hajek, and W. H. Daughaday (1977) Characterization of a protein in mid-term amniotic fluid which reacts in the Sm-c radioreceptor assay. J. Clin. Endocrinol. Metab. 44: 902-908.

Clemmons, D. R., and J. J. Van Wyk (1981) Somatomedin: Physiological control and effects on cell proliferation. In Tissue Growth Factors: Handbook of Experimental Pharmacology, vol. 57, R. Baserga, ed., pp. 161-208, Springer-Verlag, Berlin.

Clemmons, D. R., L. E. Underwood, and J. J. Van Wyk (1981) Hormonal control of immunoreactive somatomedin by cultured human fibroblasts. J. Clin. Invest. 67: 10-19.

Clemmons, D. R., R. G. Elgin, V. K. M. Han, S. J. Casella, A. J. D'Ercole, and J. J. Van Wyk (1986) Cultured fibroblast monolayers secrete a protein that alters the cellular binding of somatomedin-C/ insulin-like growth factor. Int. J. Clin. Invest. 77: 1548-1556.

D'Ercole, A. J., and J. R. Wilkins (1984) Affinity labeled somatomedin-C binding proteins in rat sera. Endocrinology 114:1141-1144.

D'Ercole, A. J., D. R. Willson, and L. E. Underwood (1980) Changes in the circulating form of somatomedin-C during fetal life. J. Clin. Endocrinol. Metab. 51: 674-676.

Drop, S. L. S., G. Valiquette, H. J. Guyda, M. T. Corval, and B. I. Posner (1979) Partial purification and characterization of a binding protein for insulin-like activity in human amniotic fluid: A possible inhibitor of insulin-like activity. Acta Endocrinol. (Copenh.) 90: 505518.

Drop, S. L. S., D. J. Kortleve, and H. J. Guyda (1984a) Isolation of a somatomedin-binding protein from preterm amniotic fluid. Development of a radioimmunoassay. J. Clin. Endocrinol. Metab. 59: 899-907.

Drop, S. L. S., D. J. Kortleve, H. J. Guyda, and B. I. Posner (1984b) 
Immunoassay of a somatomedin-binding protein from human amniotic fluid. Levels in fetal, neonatal, and adult sera. J. Clin. Endocrinol. Metab. 59: 908-915.

Elgin, R. G., W. H. Busby, and D. R. Clemmons (1987) An insulinlike growth factor (IGF) binding protein enhances the biological response to IGF. Proc. Nat1. Acad. Sci. USA 84: 3254-3258.

Furlanetto, R. W., L. E. Underwood, J. J. Van Wyk, and A. J. D'Ercole (1977) Estimation of somatomedin-C levels in normal and patients with pituitary disease by radioimmunoassay. J. Clin. Invest. 60:648657.

Gjedde, F. (1967) Insulin binding proteins in normal serum. The in vitro association of homologous ${ }^{125}$ I-labelled insulin and normal serum proteins. Acta Physiol. Scand. 70: 69-79.

Grizzard, J. D., A. J. D’Ercole, J. R. Wilkins, B. M. Moat-Staats, and R. W. Williams (1984) Affinity labeled somatomedin-C receptors and binding proteins from the human fetus. J. Clin. Endocrinol. Metab. 58: 535-543.

Han, V. K. M., J. M. Lauder, and A. J. D'Ercole (1987) Characterization of somatomedin/insulin-like growth factor receptors and correlation with biologic action in cultured neonatal rat astroglial cells. J. Ncurosci. 7: 501-511.

Hintz, R. L. (1984) Plasma forms of somatomedin and the binding protein phenomenon. In Tissue Growth Factors: Clinics in Endocrinology and Metabolism, vol. 13, W. H. Daughaday, ed., pp. 31-42, Saunders, London.

Hossenlopp, P., D. Seurin, B. Segovia-Quinson, S. Hardouin, and M. Binoux (1986) Analysis of serum insulin-like growth factor binding proteins using Western blotting: Use of the method for titration of the binding proteins and competitive binding studies. Anal. Biochem. 154: 138-143.

Kiess, W., L. A. Greenstein, R. M. White, L. Lee, M. M. Rechler, and S. P. Nissley (1987) Type II insulin-like growth factor receptor is present in the rat serum. Proc. Natl. Acad. Sci. USA 84: 7720-7724.

Knauer, D. J., and G. L. Smith (1980) Inhibition of biological activity of multiplication-stimulating activity by binding to its carrier protein. Proc. Natl. Acad. Sci. USA 77: 7252-7256.

Knauer, D. J., F. W. Wagner, and G. L. Smith (1981) Purification and characterization of multiplication-stimulating activity (MSA) carrier protein. J. Supramol. Struct. Cell. Biochem. 15: 177-191.

Laemmli, U. K. (1970) Cleavage of structural proteins during the assembly of the head of bacteriophage T4. Nature 27: 680-682.

McCarthy, K. D., and J. de Vellis (1980) Preparation of separate astroglial and oligodendroglial cell cultures from rat cerebral tissues. J. Cell Biol. 85: 890-902.

McMorris, F. A., T. M. Smith, S. DeSalvo, and R. W. Furlanetto (1986) IGF-I/somatomedin-C: A potent inducer of oligodendrocyte development. Proc. Natl. Acad. Sci. USA 83: 822-826.

Moses, A. C., S. P. Nissley, K. L. Cohen, and M. M. Rechler (1976) Specific binding of a somatomedin-like polypeptide in rat serum depends on growth hormone. Nature 263: 137-140.

Moses, A. C., S. P. Nissley, J. Passamani, and R. M. White (1979) Further characterization of growth hormone-dependent somatome- din-binding proteins in rat serum and demonstration of somatomedin-binding proteins produced by rat liver cells in culture. Endocrinology 104: 536-546.

Moses, A. C., A. J. Freinkel, B. B. Knowles, and D. P. Aden (1983) Demonstration that a human hepatoma cell line produces a specific insulin-like growth factor carrier protein. J. Clin. Endocrinol. Metab. 56: 1003-1008.

Mottola, C., R. G. MacDonald, J. L. Brackett, J. E. Mole, J. K. Anderson, and M. P. Czech (1986) Purification and amino-terminal sequence of an insulin-like growth factor binding protein secreted by rat liver BRL-3A cells. J. Biol. Chem. 261: 11180-11188.

Nissley, S. P., and M. M. Rechler (1984) Insulin-like growth factors: Biosynthesis, receptors and carrier proteins. In Hormonal Proteins and Peptides, vol. 12, C. H. Li, ed., pp. 128-203, Academic, New York.

Nissley, S. P., M. M. Rechler, A. C. Moses, P. A. Short, and J. M. Podskalny (1977) Proinsulin binds to a growth peptide receptor and stimulates DNA synthesis in chick embryo fibroblasts. Endocrinology 101: 708-716.

Rechler, M. M., H. J. Eisen, O. Z. Higa, S. P. Nissley, A. C. Moses, E. E. Schilling, I. Fcnnoy, C. B. Bruni, L. S. Phillips, and K. L. Baird (1979) Characterization of a somatomedin (insulin-like growth factor) synthesized by fetal rat liver organ cultures. J. Biol. Chem. 25 . 7942-7950.

Romanus, J. A., J. E. Terrell, Y. W.-H. Yang, S. P. Nissley, and M. M. Rechler (1986) Insulin-like growth factor carrier proteins in neonatal and adult rat serum are immunologically different: Demonstration using a new radioimmunoassay for the carrier protein from BRL-3A rat liver cells. Endocrinology 118: 1743-1758.

Smith, G. L. (1984) Somatomedin carrier proteins. Mol. Cell. Endocrinol. 34: 83-89.

Svoboda, M. E., and J. J. Van Wyk (1985) Purification of somatomedin-C/insulin-like growth factor I. In Methods in Enzymology, L. Birnbaumer and B. O'Malley, eds., pp. 798-816, Academic, New York.

Svoboda, M. E., J. J. Van Wyk, D. G. Klapper, R. E. Fellows, F. E. Grissom, and R. J. Schlueter (1980) Purification of somatomedin-C from human plasma: Chemical and biological properties, partial sequence analysis and relationship to other somatomedins. Biochemistry 19: 790-797.

Van Wyk, J. J., M. E. Svoboda, and L. E. Underwood (1980) Evidence from radioligand assays that somatomedin-C and insulin-like growth factor I are similar to each other and different from other somatomedins. J. Clin. Endocrinol. Metab. 50: 206-208.

White, R. M., S. P. Nissley, P. A. Short, M. M. Rechler, and I. Fennoy (1982) Developmental pattern of a serum binding protein for multiplication stimulating activity in the rat. J. Clin. Invest. 69: 12391252.

Wilkins, J. R., and A. J. D'Ercolc (1985) Affinity labclcd plasma somatomedin-C/insulin-like growth factor I binding proteins: Evidence of growth hormone dependence and subunit structure. J. Clin. Invest. 75: 1350-1356. 